\title{
Opportunities, Challenges and Strategies: A Current Overview of Commentaries Towards the Singapore Convention Within China
}

\author{
Chen Shen ${ }^{1}$ \\ ${ }^{1}$ School of Law, University of Chinese Social Science Academy, Beijing, China \\ Correspondence: Chen Shen, School of Law, University of Chinese Social Science Academy, Beijing, China. Tel: \\ 86-151-3803-9786. E-mail: b19500279@ucass.edu.cn
}

Received: September 15, 2021

Accepted: October 7, $2021 \quad$ Online Published: November 29, 2021

doi:10.5539/ass.v17n12p61

URL: https://doi.org/10.5539/ass.v17n12p61

This work was supported by the [National Social Science Foundation of China \#1] under Grant [18ZDA144]; [Chinese Academy of Social Sciences \#2] under Grant [Construction Project of Litigation Law in Key Disciplines]; Major Project of [Beijing Law Society \#3] under Grant [BLS (2020) A005].

\begin{abstract}
Even though the Singapore Convention is recognized as a landmark in the history of the international dispute resolution area, it is still in its infancy. Given China's economic influence and Hong Kong's position in the Asia-Pacific commercial dispute resolution market, China's ratification would greatly enhance the Singapore Convention's impact in international commercial dispute resolution market and hence promote the use of commercial mediation. However, it remains uncertain as to whether, when and how the Singapore Convention would enter into force in China, even though China's one of the first signatories. Current commentaries within China towards Singapore Convention do not only reflect the potential benefits for China to ratify the Singapore Convention, but also difficulties that China might face and strategies to overcome these difficulties, which might form the basis for future decision-makings related to commercial mediation in China.
\end{abstract}

Keywords: Singapore Convention, commercial mediation, Asia-pacific region

\section{Introduction}

On June 25 2018, UNCITRAL finalized the text of the United Nations Convention on International Conciliation Agreements resulting from Mediation (hereinafter referred to as the Singapore Convention), which was adopted by the 73rd United Nations General Assembly on 20 December 2018 (General Assembly, 2018). The Singapore Convention seeks to address the lack of enforceability of settlement agreements resulting from mediation by providing a direct relief mechanism ${ }^{1}$ for such settlement agreements, which is modelled on the New York Convention. The Convention provides a legally binding international framework, under which settlement agreements could circulate cross-border (Schnabel, 2019), and thereby promotes mediation as an important tool for alternative and effective methods of resolving commercial disputes. The Singapore Convention is recognized by Chinese commentators as a landmark in the history of the international commercial dispute resolution area (Sun, 2021; Tang, 2019; Cheng, 2020). The Singapore Convention, together with the New York Convention, the Hague Conference on Choice of Court Agreements and the Hague Convention on the Enforcement of Judgments, constitutes one of the three pillars in the field of international commercial disputes (Liu, Sun, Fu, \& Sun, 2020).

The construction of a relief mechanism for international commercial mediated settlement agreements started from a proposal made by the United States government, in which the United States government specified that an obstacle to the use of mediation in international commercial disputes was that settlement agreements reached through mediation might be more difficult to enforce than arbitral awards, and that it was therefore necessary to

\footnotetext{
${ }^{1}$ In article 4 and article 5 of the Convention, it refers to the enforcement of a settlement agreement under article 3.1 , or the invocation of a settlement agreement under article 3.2, by seeking and granting relief. See, UNCITRAL, ' Settlement of commercial disputes International commercial mediation: draft convention on international settlement agreements resulting from mediation, A/CN.9/942', (02 Mar 2018)< https://undocs.org/en/A/CN.9/942>accessed 8 Aug 2020. Relief, or relief mechanism, used in this article also refers to the enforcement of a settlement agreement or the invocation of a settlement agreement under article 3 of the Convention.
} 
provide a corresponding enforcement mechanism for settlement agreements along the lines of the New York Convention (UNCITRAL, 2014). Based on that proposal, Working Group II of the United Nations Commission on International Trade Law discussed and assessed the feasibility and possible forms of a cross-border direct relief mechanism (UNCITRAL Working Group II, 2015). Although in that meeting the majority of delegates were not optimistic about such a mechanism (Schnabel, 2019; UNCITRAL, 2015), the Working Group was formally mandated by UNCITRAL at its 48th session to work on the topic (General Assembly, 2015). After three years of discussions and compromises made among representatives of different countries and practitioners in the field of international commercial disputes, Singapore Convention was finalized.

The Singapore Convention was signed by 46 countries (Guo , 2019), including China, in Singapore on 7 August 2019. As of August 2021, the Singapore Convention has been signed by 55 countries and is in force in Belarus, Ecuador, Fiji, Qatar, Saudi Arabia, Singapore (UNCITRAL Working Group II, Status: Singapore Convetion, 2021). However, compared to the 168 Parties to the New York Convention (UNCITRAL Working Group II, 2021) and the 32 Parties to the Hague Convention on Choice of Court (HCCH, 2021), the Singapore Convention is still in its infancy in the field of international commercial dispute resolution. The Singapore Convention is intended to fulfil the role of the New York Convention for arbitration in the area of international mediation (Anderson, 2020), and it will take time to achieve this goal. In order to have a substantive influence on the decision-making of parties to international commercial disputes, not only the numbers of Parties to the Convention matters, but also the economic influences of the Parties in the global market would be of vital importance.

As the world's second largest economy and the world's largest developing country, China's ratification would have an impact on the integrity of the Singapore Convention's global implementation with no doubts (Liu, Sun, $\mathrm{Fu}, \&$ Sun, 2020). And Given Hong Kong's leadership position in the Asia-Pacific commercial dispute resolution market, China's ratification would also be crucial in reshaping the development of the Asia-Pacific commercial mediation market. Therefore, whether, when and how China would ratify and land the Singapore Convention, would not only largely affect the future development of the Singapore Convention in the field of international commercial dispute resolution, but would also be the key for the development of the international commercial mediation market in the Asia-Pacific region, which in turn would decide the willingness of parties to international commercial disputes to use mediation.

China has been one of the first signatories to the Singapore Convention, however, there are still many uncertainties as to whether, when and how the Convention will enter into force in China. According to Article 7 of the Law of Procedures for Concluding Treaties in China, after the treaty has been signed, it still needs to be ratified by statutory procedures, 'The Ministry of Foreign Affairs or the relevant department of the State Council, in conjunction with the Ministry of Foreign Affairs, shall submit it to the State Council for examination; the State Council shall submit it to the Standing Committee of the National People's Congress for a decision on ratification; the President of the People's Republic of China shall, in accordance with the decision of the Standing Committee of the National People's Congress The President of the People's Republic of China shall ratify it in accordance with the decision of the Standing Committee of the National People's Congress. ...... After the multilateral treaties and important agreements have been ratified, the Ministry of Foreign Affairs shall carry out the procedure of depositing the instruments of ratification with the depositary State or international organization of the treaty or agreement. The instrument of ratification shall be signed by the President of the People's Republic of China and countersigned by the Minister for Foreign Affairs'.

Even after the ratification, the domestic application of the Singapore Convention in China would still requires corresponding legislative support. Generally speaking, conventions could be applied in two ways in China. One is to incorporate certain terms into the provisions of current laws and regulations without converting the content of the conventions, which would clearly stipulate that the convention takes precedence and can be applied directly, for example, Article 142 of the General Principles of the Civil Law, Article 17 of the Trademark Law and Article 1 of the Notice of the Ministry of Foreign Trade and Economic Cooperation on Several Issues to be noted in the Implementation of the United Nations Contract for the International Sale of Goods, etc. The other approach is to convert the content of the conventions through legislative transformation into domestic law. For this illustration, the Law on the Territorial Sea and Contiguous Zone, the Law on the Exclusive Economic Zone and Continental Shelf, the Regulations on Diplomatic Privileges and Immunities and the Regulations on Consular Privileges and Immunities.

Conventions regulating the relations of rights and obligations between private persons, and between the State and private persons, which would normally rely on domestic legal procedure rules for private persons to make claims, raise not only the question of how to apply the rules created by the treaties in China's domestic legal 
procedures, but also the question of the compatibility of domestic law with conventions (Che, 2005).

As the core obligations under Article 3 of the Singapore Convention must rely on the domestic procedural law of its Parties, the Convention presents China with great opportunities for development as well as a bunch of challenges. How China perceives these opportunities and challenges coming with the Convention, and how would China react to overcome these challenges would form the basis for future decision-making in China.

For that purpose, the first part of this paper analysed the opportunities that ratification of the Singapore Convention might bring for China. The second part reviewed the challenges that China might face in ratifying the Convention. The third part discussed the possible strategies and solutions that China may adopt to address these challenges. Finally, it predicted China's consideration and intention to ratify the Singapore Convention, taking into account the above opportunities and challenges as well as possible strategies and solutions.

\section{Opportunities that China could see through the Singapore Convention}

Before signing ceremony hosted by Singapore, there were disagreements among the Chinese authorities as to whether to sign the Singapore Convention (Sun, 2021). However, given the importance of the Singapore Convention in the field of international commercial dispute resolution and the fact that Chinese representatives participated in the drafting process and fully expressed China's position and concerns, China finally decided to sign the Convention as one of the first signatories. But the hesitation showed that China always had doubts about landing the Singapore Convention from the beginning.

However, as things stand now, both practitioners and academics are supportive of ratifying the Singapore Convention. Wen Xiantao, Director of the Department of Treaty and Law at the Ministry of Commerce, believes that ratification to the Singapore Convention would be a solid step forward in China's pursuit of pluralistic settlement of commercial disputes (Wen, 2019). Professor Fan Yu believes that the Singapore Convention has created a major opportunity for the development of commercial mediation around the world and that China needs to seize this opportunity to promote commercial mediation towards a promising future (Fan, 2020).

The most straightforward benefit of ratifying the Singapore Convention is to promote the overall development of commercial mediation in China (Duan, 2020). At the level of commercial mediation concept, there are gaps between the role of mediators ${ }^{2}$ and the concept of mediation ${ }^{3}$ in China's domestic mediation system, and those things in the Singapore Convention. Ratification of the Convention will renew the concept of commercial mediation in China and bring domestic mediation theory and practice in line with international commercial mediation market. At the level of mediation institutionalization, the ratification will force China to invest in the formation and improvement of basic legislations, procedural rules and technical standards of commercial mediation. At the market level, it will encourage China to pay attention to the training of commercial mediation personnel and the construction of commercial mediation institutions, enhance the competitiveness of commercial mediation services and promote the development of the domestic commercial mediation market.

On top of the above benefits, the Singapore Convention can bring different opportunities for China at both international and domestic levels. At the international level, the Convention provides an opportunity for China to increase its international discourse power and enhance the influence and competitiveness of Chinese commercial mediation in the international commercial mediation market. And in the domestic context, the Convention would also provide a pathway for the realisation of China's policies in recent years.

\subsection{Opportunities at the International Level}

As China's economic development gains attentions in global community with the gradual progress of Reform and Openning up, the rule of law in relation to foreign affairs has become an important part of Xi Jinping's government's strategy for socialism with Chinese characteristics.

On January 18 2017, in a speech at the United Nations headquarters in Geneva, Xi Jinping made it clear that China wants to promote changes in global governance and build a community of human destiny (Xi, 2021). In

\footnotetext{
${ }^{2}$ In Chinese traditional mediation, parties of disputes favors a third person or persons with some kind of authority to help them reach a settlement, and in the current mediation practice in China, mediators might give advices on the substantive issues in disputes, and guide or even instruct the disputants to settle. See Liu, et al., 'A study on the challenges'. Also see, Jerome Alan Cohen, 'Chinese Mediation on the Eve of Modernization' (1966) 54 Calif L Rev 1201. Dorcas Anderson, 'The evolving concept of access to justice in Singapore's mediation movement,' (2020) 16 International Journal of Law in Context, 2020128.

${ }^{3}$ Chinese society believe that 'Peace is precious (和为贵)' and favors mediation for that, which values more on preserving harmony than on maximizing party autonomy, and leads to societal pressures on disputants. See Wen, 'The Singapore Convention and Mediation'(above).
} 
2018, the constitutional amendment clearly states in the preamble that China wants to 'develop diplomatic relations, and economic and cultural exchanges with other countries, and promote the building of a community of human destiny'. On November 16 2020, at the Central Working Conference on the Comprehensive Rule of Law, Xi Jinping stressed the need to adhere to an integrated approach to the rule of law domestic and abroad, and made a series of deployments and requirements $(\mathrm{Xi}, 2021)$.

On the macro level, the strategy require to accelerate the strategic layout of foreign-related rule of law, to coordinate the promotion of domestic and international governance, and to better safeguard national sovereignty, security and development interests. In the field of legislation and justice, it is required to accelerate the formation of a systematic and comprehensive system of foreign-related laws and regulations, and to enhance the effectiveness of foreign-related law enforcement. At the level of social management, enterprises and citizens should be guided to more consciously abide by local laws, regulations and customs in the process of going global, and to safeguard their rights and interests according to laws. In the area of dispute resolution, the attention should be focused on nurturing a number of first-class international arbitration institutions and law firms, so as to effectively safeguard and serve the rule of law in foreign-related affairs.

As China is the largest trading partner of more than 120 countries and regions worldwide (Han \& Guan, 2021), cross-border commercial activities are frequent, and prevention and resolution of international trade and economic disputes has become an important partt of China's foreign-related rule of law. As a major economic power in the global community, China needs to use the international civil litigation system to protect its interests globally, and as a major power in the rule of law, it needs to improve its judicial services and enhance the attractiveness of the Chinese judicial system in the global dispute resolution market (He, 2017).

The Singapore Convention provides China with just such an opportunity. On the one hand, the Convention gives Chinese enterprises conducting trade and investment activities overseas an incentive to use mediation tools to resolve international commercial disputes. Hence, it motivates China to strengthen the legal protection of Chinese enterprises' interests, and to turn its economic advantages into dominance and voice in international commercial dispute resolution, thereby enhancing and consolidating its position in the international commercial landscape. On the other hand, the Convention provides a platform for China's commercial mediation system to enter into the global commercial dispute resolution market (Sun, 2021). The pressure of the application of the Singapore Convention will inevitably promote the modernization, internationalization and legislation of China's commercial mediation, enhance the professionalism and operational capacity of China's commercial mediation services, and further improve the international competitiveness and influence of China's dispute resolution system (Liu, Sun, Fu, \& Sun, 2020; Sun, 2021).

Besides that, Hong Kong has long been in a competitive relationship with Singapore in the Asia-Pacific commercial mediation market. And Singapore has already tied its image to international commercial mediation by hosting the Singapore Convention's signing ceremony and being one of the first signatories, one of the first ratifications and one of the first countries to enter into force (UNCITRAL Working Group II, Status: Singapore Convetion, 2021). Singapore has taken an active part in the promotion and application of the Singapore Convention at both the international and domestic levels and gained a dominant position in the field of international commercial mediation. Non-ratification of the Convention means that Hong Kong will not be able to attract parties to commercial disputes who wish to rely on settlement agreements for direct relief, which would be a disadvantage for Hongkong when competing with Singapore in the Asia-Pacific commercial mediation market.

As a unique form of dispute resolution in China, mediation has a long history in Chinese society. But due to decades of neglections of mediation in the civil justice system, China had lost its voice in the global community on the topic of commercial mediation (Liao , 2019). In the meantime, developed Western countries, like America and United Kingdoms, have made leaps in mediation. And the power of discourse regarding mediation research and rule-making gradually coming to rest in the hands of such countries. (Liao, 2019). Unlike the global context when the New York Convention was formulated and developed, China had participated in the deliberation of the Singapore Convention from the beginning. And China has the opportunity to play an active and leading role in the development and application of the Convention, so that it could contribute to the formation of new international customary law and general principles of law in the area of commercial mediation. In a word, the Convention provides a unique opportunity for China to transform itself from a rule-taker to a rule-maker and improver (Sun, 2021), to compete for international discourse and to participate in global economic governance.

\subsection{Domestic Opportunities}

From a domestic perspective, commercial mediation has become the focus of many judicial reform policies in 
China, including the diversified dispute resolution system, the optimization of the business environment and the construction of the Belt and Road dispute resolution mechanism. The Opinions of the Supreme People's Court on the People's Courts Further Deepening the Reform of the Diversified Dispute Settlement Mechanism, the Regulations on Optimizing the Business Environment promulgated by the State Council in 2019, the Opinions of the Supreme People's Court on the People's Courts Deepening the Reform of the Mechanism of 'Separate Adjustment, Adjudication and Trial' in 2020 and the Opinions of the People's Republic of China on the Reform of the 14th Session of the National Economic and Social Development Council in 2021. In 2019, the Supreme People's Court issued the 'Opinions of the People's Courts on the People's Courts' Deepening the Reform of the Mechanism of 'Separate Adjustment, Adjudication and Trial' and the 'Outline of the 14th Five-Year Plan for National Economic and Social Development and the Visionary Goals for 2035', all of which explicitly promote the improvement or perfection of the joint work system of commercial mediation, arbitration mediation, people's mediation, administrative mediation, industrial mediation and judicial mediation or the interface mechanism between commercial mediation and litigation. the construction of the 'Belt and Road' to provide judicial services and protection, 2019, the Notice of the State Council on the Issuance of the General Scheme for the Six New Free Trade Pilot Zones, 2021, the Opinions of the Supreme People's Court on the People's Courts' Provision of Judicial Services and Protection for the Construction of Hainan Free Trade Port, 2021, the Laws, regulations and policy documents such as the Law of the People's Republic of China on Hainan Free Trade Port, all emphasize the important position of international commercial mediation in the diversified commercial dispute resolution mechanism.

However, commercial mediation in China has developed quite slowly under the framework of the People's Mediation system, which would hinder the development of the commercial mediation system (Yang, 2020). The Singapore Convention, which reflects the international trends and opinions on mediation, is a good reference for reviewing the development of mediation in China (Cai, 2021), and ratification of the Convention can force China's commercial mediation system to enter into a rapid development track. With a well-developed commercial mediation system, China can provide a framework for cross-border relief for parties to settlement agreements, enlarge the advantages of commercial mediation in bridging legal and cultural differences $(\mathrm{Du}$, 2021), and avoid the breakdown of business partnerships due to commercial disputes and save parties' costs. All of above will ensure a better business environment for domestic and foreign investors, help maintain friendly international trades along the Belt and Road, so as to achieve the goal of building a human community and promote diversified dispute resolution to achieve a win-win situation for the judiciary and personalized dispute resolution in society.

\section{Chanllenges that China might face when landing the Singapore Convention}

The cross-border relief mechanism for international commercial settlement agreements under the Singapore Convention is at the forefront of institutional development by clearly affirming the enforceability of settlement agreements (Song \& Xu, 2021). While China is facing the aboved opportunities, challenges also exists in building a direct relief mechanism for international settlement agreements under the Singapore Convention (Gao, 2020). At present, China has the three major concerns about landing the Singapore Convention: the incompatibilities of commercial mediation system and practice between China and the global commercial mediation market, fraudulent mediation, and the dismatch between the envisaged enforcement mechanism and the judicial ability to provide relief according to the Convention.

\subsection{The Incompatibility of Mediation System and Practice}

There is a considerable incompatibility between China's current mediation system and practice, and the commercial mediation system envisaged by the Singapore Convention, which will create certain difficulties for China in implementing its obligations under the Convention.

\subsubsection{The Rupture in the Legislation of the Mediation System}

Although some scholars believe that in contemporary China, the emergence of modern commercial mediation can be traced back to the 2012 amendments to the Civil Procedure Law (Corne \& Erie, 2019). The reality is that there is no basic legislation in the field of commercial mediation in China and the provisions related to the commercial mediation are scattered in different laws, regulations and policies (Song \& Xu, 2021), and some scholars even believe that there is no comprehensive legislation for mediation in China (Lian, 2021).

From the perspective of legislation, People's Mediation system in China, with the People's Mediation Law as its core, has a strong administrative feature (Tang, 2019) and the resulting mediated agreements usually require judicial confirmation before they can be enforced, which is a certain degree of deviation from the direct relief system designed by the Singapore Convention. The court mediation system, which is centered on Chapter VIII of 
the Civil Procedure Code, is strongly adjudicative ( $\mathrm{Lu}, 2019)$, and the resulting mediated agreement can be enforced in line with judgments, and is directly excluded from the scope of application of Article 1(3) of the Singapore Convention. In practice, the above two mediation systems are incompatible with the framework of commercial mediation in terms of values, procedural rules and organizational context (Duan, 2020; Song \& Xu, 2021; Yang, 2020) and there are considerable departures from the direct relief regime envisaged by the Singapore Convention.

A similar situation exists in Japan's mediation system and practices, and this has seriously affected Japan's intention to accede to the Singapore Convention. Professor Kaine of the University of Tokyo notes that Japan is currently neutral and has no intention of acceding to the Singapore Convention because its civil enforcement system and ADR Act are not compatible with the cross-border relief system for settlement agreements envisaged by the Singapore Convention (Sommerville, 2019).

\subsubsection{A Break in the Use and Understanding of Terms}

The Chinese translation of the Singapore Convention describes the object of regulation as 'international settlement agreements arising from mediation', however, in the context of the Chinese civil litigation system, a settlement agreement refers to an agreement reached voluntarily by the parties to a dispute to resolve the dispute without the assistance of any third parties (Gao, 2020; Lian, 2021; Song \& Xu, 2021). And for now, the legal effect of settlement agreements is only clearly recognized in China's civil enforcement procedure. According to Article 9 of the 'Provisions of the Supreme People's Court on Several Issues of Executive Settlement' (amended in 2020) of the Supreme People's Court of China, if the executee does not fulfil the settlement agreement reached during the execution procedure, the applicant for execution may apply for 'restoration of the execution of the original legal instrument in force, or he may file a lawsuit with the execution court for the fulfilment of the execution settlement agreement.' It can be seen that such settlement agreements cannot be used as a legal title to apply fot enforcement directly, they remains the same legal effect as contracts and can only expect to go through litigation in the event of non-compliance by the executor.

In Chinese judicial practice, there are two types of documents resulted for mediation with different legal effects: mediated letters and mediation agreements. Mediated letters have the same legal effect as judgments or arbitral awards and are enforceable, and therefore may fall out the scope of Article 1(3) of the Singapore Convention. However, in accordance with the Civil Procedure Law, the Arbitration Law and the People's Mediation Law, the enforceability of mediated agreements are subject to judicial confirmation and the legal nature of mediated agreements that have not been judicially confirmed is approximately the same as a contract.

The aboved differences in terminology in the context of Chinese civil justice are not only closely decided by the procedural context, in which the agreement is obtained, but also decide the legal effect it may have.And all of these terms different from the meaning of 'settlement agreement' under the Singapore Convention.

In addition, China's existing system and practice differ from the Singapore Convention in terms of commercial disputes and the international nature of settlement agreements, which inevitably leads to uncertainty when considering to grant relief or not.

In terms of the definition of commerciality, Chinese doctrine adopts the profitability criterion, i.e. activities that do not have profit-making are generally not included in the scope of commerce ( $\mathrm{Du}, 2021)$. In the field of substantive law, China currently adopts a model of civil and commercial legislation and lacks clear legislative scope for commercial legal relationships. From the Notice of the Supreme People's Court on the Implementation of the New York Convention, it appears that China explicitly excludes disputes between foreign investors and the host government from the scope. In contrast, Article 1(2) of the Singapore Convention adopts an open-ended exclusionary enumeration of commercial disputes, with matters such as national infrastructure, matters relating to the exploitation of national natural resources or concession agreements and some disputes between investors and the host government being covered by commercial disputes (Ge, 2019).

In terms of international assessment, China currently uses the term 'foreign-related' to refer to cross-border civil and commercial legal relations. And the general term for the determination of "foreign-related" is "elemental", meaning that at least one of the three elements of the legal relationship - subject, object or content - has a connection with a foreign country (Han, 2003). In the light of Article 1 of the Interpretation of the Supreme People's Court on Several Issues Concerning the Application of the Law of the People's Republic of China on Foreign-related Civil Relations (I) (amended in 2020), a legal relationship can only be considered foreign-related if the nationality or place of habitual residence of the parties to the legal relationship, the subject matter and the legal facts belong to, are in, or occur outside of China. It's different from the international approach of the Singapore Convention, which emphasizes international rather than foreign character (UNCITRAL, Report of 
Working Group II (Arbitration and Conciliation) on the work of its sixty-third session, A/CN.9/861, 2015) and evaluates settlement agreements on the basis of the place of business of the parties to the dispute, the place of performance of the substantive obligations and the place of closest connection.

\subsubsection{Breakdown in the Recognition of Mediation Subjects}

With regard to the qualification requirements for mediation subjects, China's legislation and practice also show a departure from the Singapore Convention. It is clear from Articles 2(3), 4(1) and 5(1) of the Convention that the Convention does not require the qualifications or status of third parties to mediation, and that the relevant authorities of the place of relief should grant relief to a settlement agreement, whether mediated by an institution or by a mediator, provided that the conditions for the application of the Convention are met and that it does not constitute a situation as set out in Article 5(1). And the Convention holds against the formal requirements attached by the place of relief to the qualifications and status of the mediator.

However, for a long time, China has had an exclusive institutional management model for mediation (Sun, 2021). The judiciary currently only recognizes the legal effect of court mediation, arbitration mediation and mediation by the People's Mediation Committee. Although there is individual mediation in the field of People's Mediation, in practice, the individual mediation studio is a mediation organization named after the name the people's mediator, that mean the individual mediation studio stiil exsists under the power of People's Mediation Committee (Sun, 2021). Individual mediation exists only in isolated practices such as mediation by invited mediators of the people's courts and mediation by lawyers, both of which are highly dependent on organizations and institutions and are in fact mediators appointed by or endorsed by organizations or institutions (Sun, 2021).

The Singapore Convention's relaxed requirements for mediator qualifications and participation contrast sharply with China's reliance on the endorsement of authoritative dispute resolution institution for judicial relief. Ratification of the Convention will not only have an impact on the Chinese judiciary's treatment of domestic agreements resulting from individual mediation, but will also challenge the manner and scope of China's review of international settlement agreements.

\subsection{Fraudulent Mediation}

Fraudulent mediation is one of the biggest concerns of Chinese scholars and practitioners regarding the ratification of the Singapore Convention. And China's current heavy reliance on mediation organizations or institutions is in part to prevent fraudulent mediation from causing harm to the legitimate rights and interests of third parties or the public interests. The cross-border relief regime for commercial settlement agreements constructed by the Singapore Convention does not alleviate this concern in China and tends to further exacerbate it.

Firstly, the direct relief mechanism adopted by the Singapore Convention and its significant limitation on the scope of review by the competent authority in the place of relief not only deprives the Chinese authority of reliance on the endorsement of the judicial authority in the place of origin, but also increases the likelihood that the enforcement agency will be exposed to fraudulent mediations (Sun, 2021). Secondly, the Convention does not provide for the qualification of mediators and institutions, which is considered to be a potential obstacle to the validity of private mediations, as the settlement agreements resulting from private mediations lack credibility (Sun, 2021). Finally, the international nature of the Singapore Convention may also heighten China's concern about fraudulent mediations. Fraudulent mediations in an international context are often beyond the reach of Chinese law, and Chinese enforcement may face a major regulatory dilemma. Moreover, the cost of fraudulent mediation is low, and with the Convention as a backing, it is easy for parties to achieve their goal of fraudulent mediation (Liu, Sun, Fu, \& Sun, 2020). Finally, Article 2(3) of the Singapore Convention defines mediation in broad terms and does not require rules of procedure, organization, conduct, or participation of mediators in mediation. In light of China's concerns about fraudulent mediation, the delineation of the scope of mediation under the Convention and the circumstances of fraudulent mediation present challenges to both Chinese judicial practice and theory.

\subsection{A Mismatch Between Universal Enforcement Mechanisms and Judicial Relief}

In addition, what is closely related to the Singapore Convention's relief mechanism is the ability of China's judicial capacity to fulfil the reliefing needs that should be assumed upon ratification of the Convention.

Firstly, the phenomenon of 'difficulties in enforcement' has long been a focus of domestic judicial attention in China (Xiao \& Zhao, 2005). This phenomenon is considered to be closely related to the prevalence of local protectionism and sectoral protectionism, which, when combined with the international and foreign dimension of commercial settlement agreements, may lead to an increase in protectionist tendencies in the practice of 
implementing the Singapore Convention, resulting in judicial relief not being available.

Secondly, under the Belt and Road Initiative, China's transnational business activities are frequent and the country has the property of many foreign-related commercial subjects and China's ratification to the Singapore Convention may face the pressure of 'international transfer of cases' and 'enforcement explosion' (Sun, 2021). There is no way to know whether the existing judicial relief can cope with such pressure.

Plus, lacks of reciprocal reservation also makes evaluating legal identification and application of settlement agreements a challenge for post-ratification Chinese enforcement agencies. For example, the competent authorities may need to track and review the legal norms relating to international commercial mediation in all countries around the world in order to determine whether an international mediation agreement is valid under their governing law, which will obviously make the granting of relief more difficult (Sun, 2021).

Finally, the Chinese judicial system shows significant differences in the determination of the validity of mediated agreements and the establishment of relief procedures, from the mediation system envisaged by the Singapore Convention. Hence, the impact on the existing judicial system and the cost of reforming it while implementing the Convention are also factors that China will have to weigh carefully before acceding to the Singapore Convention.

\section{Pathways to Addressing Challenges}

While there are certainly many challenges to China's ratification of the Singapore Convention and the implementation of its international obligations under the Convention, there are also many benefits that China can receive from ratifying the Convention, both at the international and domestic levels. Therefore, ratification of the Singapore Convention has become the mainstream call in China and most scholars and practitioners believe that these challenges and concerns can be overcome through reasonable bridging measures, which are necessary not only to reap the many benefits that the Convention might bring in the future (Liu, Sun, Fu, \& Sun, 2020), but also to implement its international obligations properly and uphold the legitimacy of international commercial mediation (Cai, 2021).

Firstly, with regard to the mentioned incompatibility between the mediation system and practice, there are currently two different views in China- the dual-track and the single-track -on how to channel with the cross-border direct enforcement mechanism designed by the Singapore Convention. According to the dual-track theory, the Convention and China's current mediation system differ in their perceptions of the validity of settlement agreements (Gao, 2020), so reference should be made to the New York Convention's model of convergence with China's arbitration system. The validity of international and domestic settlement agreements should be treated differently and a corresponding relief mechanism should be designed separately, which means while international settlement agreements might be subject to a direct relief mechanism under the Convention, domestic settlement agreements should remain unchanged under the current practice. (Song \& Xu, 2021). However, for domestic settlement agreements, the current practice should be maintained, with those endorsed by mediation institutions or mediation organizations being given enforcement power after judicial confirmation and the same treatment should be considered after the domestic commercial mediation system has been improved (Zhang \& Fang, 2021). Proponents argue that the 'one-step' approach deprives the Chinese mediation system of the process of localizing the law in the process of international convergence and that the dual-track approach avoids overly radical and hasty reforms (Song \& Xu, 2021).

However, the dual-track system have been criticised for creating inequality of rights between parties and granting "supranational treatment" to foreign companies (Yang, 2020). Proponents of the single-track approach argue that there is no fundamental difference between international and domestic settlement agreements, and that, in order to promote the use of mediation, the realization of the potential benefits of the Convention necessarily requires the internationalization of domestic commercial mediation systems. And the lessons of the New York Convention interface should therefore be learnt in order to avoid differential treatment of international and domestic settlement agreements.

On the basis of the above debate, scholars are also divided as to how to structure the commercial mediation system. The mainstream view is that commercial mediation should be legislated independently (Duan, 2020). However, a small number of scholars believe that independent legislation on commercial mediation is not feasible and that it is more feasible to adopt a comprehensive mediation law (Gao, 2020).

There are currently no mature views on the prevention of fraudulent mediation in China (Cai, 2021) and the current discussions include the following trategies to deal with this: (1) Establishing procedures in the enforcement process, such as an outsider objection mechanism and a reversal of enforcement of guarantees (Dai, 
2020; Liu, Sun, Fu, \& Sun, 2020); (2) Establishing special review procedures in the enforcement review process, requiring parties to submit notarized documents, personal declarations, etc. (Liu, Sun, Fu, \& Sun, 2020), when applying for relief and even conducting a substantive review of fraudulent mediation in accordance with the public policy defense in Article 5(2) of the Singapore Convention (Sun, 2021). (3) Provide incentives or penalties for mediators to identify fraudulent mediations in the enforcement process (Liu, Sun, Fu, \& Sun, 2020). (4) Criminalizing 'fradulent mediation' by reference to Article 112 of China's Criminal Code, which provides for the criminalization of false litigation in order to achieve a deterrent effect (Sun, 2021). (5) The procuratorial system is of the view that a judicial interpretation can be issued by the Supreme People's Court to clarify that the procuratorial authorities can supervise false mediation on application or ex officio (Xie, 2021).

In response to those concerns about the mismatch between the cross-border direct relief mechanism for settlement agreements under the Singapore Convention and the capacity of judicial relief, there is general optimism in China. Firstly, as settlement agreements normally rely on self-execution, with the deterrent effect guaranteed by the Convention's corresponding direct relief mechanism, the rate of self-execution of settlement agreements is bound to increase significantly, so that the number of application for enforcement will not increase significantly (Duan, 2020). Secondly, even if there is a significant increase, it will be in the short term and the demand for judicial relief will be lower in the long term (Liu, Sun, Fu, \& Sun, 2020). The number of commercial disputes with a need for enforcement or relief in China will not change as a result of the promotion of commercial mediation and with no change in the number, commercial disputes will be resolved by litigation or arbitration, if not by mediation. And settlement agreements are reached voluntarily by the parties and should not be less self-executing than litigation or arbitration. Therefore, the number of commercial disputes that enter into litigation or arbitration proceedings, or end up in enforcement proceedings will be reduced after diversion through the commercial mediation route. Finally, with the gradual landing of the Singapore Convention and the refinement of the articulation measures, the establishment of a comprehensive relief mechanism for settlement agreements will not only provide the parties with a more convenient, friendly, efficient and economical way to settle their disputes (Bao, 2020), but will also significantly reduce the burden on the judicial system. Thus it will reach a win-win situation for both parties to commercial disputes and the civil justice system.

\section{Conclusion}

Although there are many challenges to China's ratification of the Singapore Convention and the implementation of its international obligations under the Singapore Convention, there are many benefits to be realized by China, both internationally and domestically and Chinese scholars and practitioners are generally positive about the future of the Singapore Convention in China, believing that ratification is in line with China's important concerns and long-term interests (Bao, 2020). There have been initial and extensive discussions on how to address the challenges. In light of China's domestic situation, China's ratification of the Singapore Convention is inevitable, but the government has to analyze and weigh the benefits of acceding to the Singapore Convention against the costs of converging with it.

The Singapore Convention does not provide for a reciprocal reservation mechanism, as the New York Convention does, and therefore the enforcement of international mediated agreements is universal in nature (Ge, 2019), i.e., the parties have an international obligation to provide relief to all countries (whether they are parties or not) for international mediated agreements as long as the requirements of the Singapore Convention are met. This undermines the incentive for China to accede to the Convention at the earliest opportunity on two levels, as lacks of reciprocal reservation mechanism would allow China to protect its economic interests without acceding to it, in the States, which are Parties to the Convention. On the other hand, some scholars are concerned that premature ratification to the Singapore Convention would create an imbalance between China's obligation to enforce mediated settlement agreements around the world and the inability to enforce China's mediated settlement agreements in the non-party states (Ge, 2019).

By waiting until the international commercial mediation system, with the Singapore Convention at its core, has matured, it will be possible to draw on the mature systems of other countries (Sun, 2021). And the actual value of the Singapore Convention for China will largely depend on the level of participation of international dispute resolution centers and economic powers $(\mathrm{Gao}, 2020)$ and it may seem more beneficial to wait and see how other countries will behave before joining.

However, Singapore and Hong Kong are in a highly competitive relationship in the field of international commercial dispute resolution in the Asia-Pacific region and Singapore has already tied its international image to international commercial mediation by hosting the signing ceremony for the Singapore Convention and has taken the lead in ratifying the Singapore Convention through the enactment of the Mediation Act 2020. 
Therefore, in terms of maintaining Hong Kong's status as a centre for international commercial dispute resolution, as well as competing for voice and market share in international commercial mediation, early ratification to the Singapore Convention is of vital importance for China.

The choice of the articulation path also depends on the timing of ratification. If China can maximise the benefits of the statute of limitations by acceding as soon as possible, then a temporary 'supranational treatment' of international settlement agreements and a step-by-step reform of the domestic commercial mediation system may be the best path. However, if there are no significant short-term benefits to China in terms of immediate ratification, then it would be more logical for China to reform and internationalise its domestic commercial mediation system before ratifying it.

\section{References}

Anderson, D. Q. (2020). A matter of interpretation? Understanding and applying mediation standards for the cross-border enforcement of mediated settlement agreements. Conflict Resolution Quarterly, 38, 27-45. https://doi.org/10.1002/crq.21285

Bao, K. (2020). The Advantage of Backwardness within the Singapore Convention on Mediation and China's Stance. Wuhan University International Law Review, 15-36.

Cai, W. (2021). Reform of Commercial Mediation in China in the Light of the Singapore Convention on Mediation. Anhui University Journal, 114-122.

Che, P. (2005). On the application of treaties in China. Journal of Law, 96-99.

Cheng, H.-E. (2020). The Development of the Rule of Law in Relation to Foreign Affairs in the Context of the Innovation of the Enforcement Mechanism of the Singapore Convention on Mediation by Chinses Courts. Journal of Law Application, (4), 46-54.

Corne, P. H., \& Erie, M. S. (2019, Aug 28). China's Mediation Revolution? Opportunities and Challenges of the Singapore Convention. Retrieved from Opiniojuris: http://opiniojuris.org/2019/08/28/chinas-media-revolution-opportunities-and-challenges-of-the-singapore-m ediation-convention/

Dai, X. (2020). Exploring the path of enforcement of international commercial settlement agreements in China under the Singapore Convention on Mediation. Journal of International Economic Law, 37-48.

Du, J. (2021). Reflections on the Rule of Law in International Commercial Mediation in China. National Judges College Law Journal, 150-156.

Duan, M. (2020). The Impact of the Singapore Convention and the Response of Chinese Commercial Mediation. Commercial Research, 129-137.

Fan, Y. (2020). The past, present and future of commercial mediation. Commercial Arbitration \& Mediation, (1), 126-141. https://doi.org/10.4324/9781003122845-9

Gao, Q. (2020). On the Cross-Border Enforcement of International Settlement Agreements in China: A Theoretical Analysis and Institutional Construct. Theory Monthly, (8), 96-108.

Ge, H. (2019, Feb 19). The Singapore Convention's Universal Dividend is a Double-Edged Sword. Retrieved from http://www.legaldaily.com.cn/index/content/2019-02/19/content_7772671.htm

General Assembly. (2015, Jul 16). Report of the United Nations Commission on International Trade Law, A/70/17. Retrieved from ttps://undocs.org/en/A/70/17

General Assembly. (2018, 7 13). Report of the United Nations Commission on International Trade Law, A/RES/73/198. Retrieved from https://undocs.org/en/A/RES/73/198

Guo, T. (2019, Aug 8). The United Nations Convention on International CMediation Agreements resulting from Mediation was signed today by Assistant Minister Li Chenggang on behalf of the Chinese Government. Retrieved from http://www.ccpit.org/Contents/Channel_4250/2019/0808/1194725/content_1194725.htm

Han, Y., \& Guan, X. (2021, Mar 19). China Gravitational Field. Retrieved from https://www.chinanews.com/gn/2021/03-19/9435646.shtml

Han, D. (2003). New Theory of Private International Law. Wuhan: Wuhan University Press.

HCCH. (2021, Sep 8). \#37 - Status table. Retrieved from https://www.hcch.net/en/instruments/conventions/status-table/?cid=98 
He, Q. (2017). The Concept of Great Power Justice and the Development of China's International Civil Litigation System. China Social Science, 123-146+208.

Lian, J. (2021). On the Difficulties and Breakthroughs of Enforcement of Settlement Agreements Resulting from International Commercial Mediation: The Compatibility of Singapore Convention with China's Legal System. International Business Research, 42(1), 50-62.

Liao , Y.-A. (2019). Conceptual Innovation and Institutional Reshaping of Mediation in China. Beijing: China Renmin University Press.

Liu , J., Sun, W., Fu , P.-f., \& Sun, N. (2020). A study on the challenges of ratifying the Singapore Convention on Mediation and How to Respond to Them. Commercial Arbitration \& Mediation, (1), 45-60.

Lu, X. (2019). The 'Adjudicative Mediation' Phenomenon in Perspective: The Pluralistic Positioning of 'Clarity of Matters and Responsibilities' in Litigation Mediation. Jurists, 101-111+193-194.

Schnabel, T. (2019). The Singapore Convention on Mediation: A Framework for the Cross-Border Recognition and Enforcement of Mediated Settlements. Pepp Disp Resol L. J., 19(1), 1-60. https://doi.org/10.2139/ssrn.3239527

Sommerville, O. (2019, Sep 16). Singapore Convention Series - Strategies of China, Japan, Korea and Russia. Retrieved from Mediationblog: http://mediationblog.kluwerarbitration.com/2019/09/16/singapore-convention-series-strategies-of-china-jap an-korea-and-russia/

Song, L.-b., \& Xu, Y.-r. (2021). Studies on the Enforceability of Commercial Mediated Settlement Agreements in China: In the Background of the Enforcement of the Singapore Convention. Journal of Northwest University, 51(1), 21-32.

Sun, N. (2021). Ratification and implementation of the Singapore Convention in China. Chinese Journal of Law, 43(2), 156-173.

Tang, Q.-q. (2019). Bettering Chinese Commercial Mediation Mechanism in the Context of Singapore Convention. Journal of Shanghai University, 36(4), 116-129.

UNCITRAL. (2014, 6 2). Planned and possible future work - Part III, Proposal by the Government of the United States of America: Future work for Working Group II, A/CN.9/822. Retrieved from https://undocs.org/en/A/CN.9/822

UNCITRAL. (2015, Feb 11). Report of Working Group II (Arbitration and Conciliation) on the work of its sixty-second session, A/CN.9/832. Retrieved from https://undocs.org/en/A/CN.9/832

UNCITRAL. (2015, Fe). Report of Working Group II (Arbitration and Conciliation) on the work of its sixty-second session, A/CN.9/832. Retrieved from https://undocs.org/en/A/CN.9/832

UNCITRAL. (2015, Feb 11). Report of Working Group II (Arbitration and Conciliation) on the work of its sixty-second session, A/CN.9/832. Retrieved from https://undocs.org/en/A/CN.9/832

UNCITRAL. (2015, Sep 17). Report of Working Group II (Arbitration and Conciliation) on the work of its sixty-third session, A/CN.9/861. Retrieved from https://undocs.org/en/A/CN.9/861

UNCITRAL Working Group II. (2015, Feb 2). Settlement of commercial disputes: Enforceability of settlement agreements resulting from international commercial conciliation/mediation A/CN.9/WG. II/WP.187. Retrieved from https://undocs.org/en/A/CN.9/WG.II/WP.187

UNCITRAL Working Group II. (2021, Sep 8). Status: New York Convention. Retrieved from https://uncitral.un.org/en/texts/arbitration/conventions/foreign_arbitral_awards/status2

UNCITRAL Working Group II. (2021, Sep 8). Status: Singapore Convetion. Retrieved from https://uncitral.un.org/en/texts/mediation/conventions/international_settlement_agreements/status

Wen, X. (2019). The Singapore Convention and Commercial CMediation in China - A Comparison with the New York Convention Convention on Choice of Court Agreements. China Law Review, 198-208.

Xi, J. (2021, Jan 1). Building a community of human destiny together. Retrieved from http://www.xinhuanet.com/politics/leaders/2021-01/01/c_1126936802.htm

Xi, J. (2021, Feb 28). To unswervingly follow the path of socialist rule of law with Chinese characteristics and to provide a strong guarantee of the rule of law for the comprehensive construction of a modern socialist country. Retrieved from https://www.ccdi.gov.cn/ldhd/gcsy/202103/t20210301_236691.html 
Xiao, J., \& Zhao, J. (2005). Exploring Some Difficult Issues in Civil Enforcement. National Judges College Law Journal, 2-8.

Xie, W. (2021, Mar 5). He Hengyang Representative: Proposal to clarify the supervision of false mediation by the procuratorial authorities. Retrieved from https://www.spp.gov.cn/spp/zdgz/202103/t20210305_510661.shtml

Yang, B. (2020). Revisiting the Singapore Convention on Mediation and the Development of China's Commercial Mediation System. Beijing Arbitration, 107-120.

Zhang, Y., \& Fang, X. (2021). A study on the enforceability of commercial mediated agreements in China under the Singapore Convention. National Judges College Law Journal, 38-45.

\section{Copyrights}

Copyright for this article is retained by the author(s), with first publication rights granted to the journal.

This is an open-access article distributed under the terms and conditions of the Creative Commons Attribution license (http://creativecommons.org/licenses/by/4.0/). 